\title{
THE POTENCY OF SUMBA ONGOLE (SO) CATTLE: A STUDY OF GENETIC CHARACTERIZATION AND CARCASS PRODUCTIVITY
}

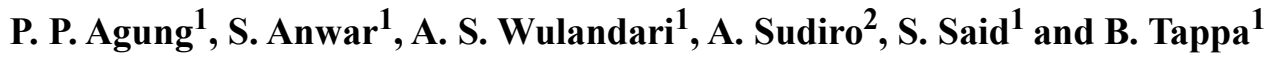 \\ ${ }^{1}$ Research Center for Biotechnology-Indonesian Institute of Sciences (LIPI), \\ Jl. Raya Bogor KM. 46, Cibinong 16911, West Java - Indonesia \\ ${ }^{2} P T$. Karya Anugerah Rumpin (PT. KAR), \\ Jl. Raya Cibodas No. 99, Rumpin, West Java - Indonesia \\ Corresponding E-mail: paskah_partogi@yahoo.com \\ Received April 09, 2015; Accepted May 26, 2015
}

\begin{abstract}
ABSTRAK
Telah dilakukan suatu penelitian untuk mengevaluasi keragaman genetik sapi Sumba Ongole (SO) berdasarkan DNA mikrosatelit dan mengkaji potensi sapi SO sebagai sapi potong lokal Indonesia berdasarkan kemampuan produksi karkasnya. Sebanyak 28 sampel darah sapi SO digunakan untuk melakukan karakterisasi genetik menggunakan 12 pasang primer DNA mikrosatelit yang direkomendasikan oleh FAO. Data produksi karkas dan bobot kulit berasal dari 506 ekor sapi SO yang dipotong di rumah potong hewan Karawaci, Banten, Indonesia. Nilai heterozigositas 12 lokus mikrosatelit berkisar antara 0,143 sampai dengan 1,000 (rata-rata 0,536). Nilai PIC tertinggi $(0,814)$ ditemukan pada lokus TGLA122 sedangkan nilai terendah $(0,280)$ ditemukan pada lokus BM1818. Sapi dengan bobot potong 351-475 kg merupakan sapi yang paling banyak dipotong pada tahun 2013 dan 2014 dengan persentase karkas antara 52,89\% sampai dengan 53,43\%. Persentase karkas tertinggi $(56,34 \%)$ diperoleh dari sapi dengan bobot potong $626-650 \mathrm{~kg}$. Sementara itu persentase karkas terendah $(51,42 \%)$ diperoleh dari sapi dengan bobot potong $250-275 \mathrm{~kg}$. Hasil karakterisasi genetik menunjukkan bahwa seluruh lokus mikrosatelit berada dalam kondisi beragam dan dapat digunakan untuk mendeteksi level keragaman genetik populasi sapi SO. Hasil studi produksi karkas menunjukkan bahwa sapi SO memiliki potensi yang sangat baik sebagai sapi potong bila dibandingkan dengan bangsa sapi potong lokal lain di Indonesia.
\end{abstract}

Kata kunci: karakterisasi, genetik, Sumba Ongole, karkas, potensi sapi

\begin{abstract}
A study was conducted to assess the genetic characterization of the Sumba Ongole (SO) cattle based on DNA microsatellites and also to study the potency of SO cattle based on carcass productivity. Blood samples were collected from 28 individual cattle and 12 microsatellite primers as recommended by FAO were used to identify the genetic characterization of the SO cattle population. Data of carcass productivity were collected from 506 individual cattle that slaughtered in Karawaci abattoir, Banten, Indonesia. The heterozygosity values of microsatellite loci ranged from 0.143 to 1.000 (mean 0.536 ). The highest PIC values was 0.814 (locus TGLA122), while the lowest was 0.280 (locus BM1818). Cattle in range of 351-475 kg slaughter weight was most slaughtered in year 2013 and 2014 with carcass percentage ranged from $52.89 \%$ to $53.43 \%$. The highest carcass percentage $(56.34 \%)$ was obtained from cattle in range of $626-650 \mathrm{~kg}$ slaughter weight while the lowest $(51.42 \%)$ was obtained from cattle in range of $250-275 \mathrm{~kg}$ slaughter weight. The results of genetic characterization showed that all microsatellite locus were highly polymorphic and highly informative for detecting the level of genetic diversity in the SO cattle population. The results of carcass productivity showed that the SO cattle has excellent potential as beef cattle compare with other local breeds cattle in Indonesia.
\end{abstract}

Keywords: genetic, characterization, Sumba Ongole, carcass, beef cattle potency 


\section{INTRODUCTION}

Sumba Ongole (SO) cattle is one of Indonesian local breeds cattle. The existence of the SO cattle in Indonesia began since the Ongole cattle was imported from India in 1914 (Ministry of Agriculture of the Republic of Indonesia, 2014) and placed in Sumba island (East Nusa Tenggara Province) and well adapted in Indonesian climate. The Sumba island eventually set for Ongole cattle breeding center that became known as Sumba Ongole cattle (Hardjosubroto, 2004). Meat production percentage of the SO cattle was fairly high and percentage of carcass fat was low (Ngadiyono, 1995). The SO cattle can be used in fattening (feedlots), especially fattening in a relatively long period and gain a high slaughter weight. Carcass of the SO cattle are longer and wider than Brahman cross cattle (Ngadiyono, 1995).

Up to present, almost no reports about genetic diversity of the SO cattle. Information about genetic diversity is needed to perform conservation program especially in Indonesian local cattle resources and also provide an opportunity for farmers to develop animal breeding bussiness. The development of molecular genetics analysis has made it possible to study into deoxyribonucleic acid (DNA) level. Microsatellites are almost ideal genetic markers because they are abundant, codominant, highly polymorphic, and spread across the entire euchromatic part of the genome (Bennett, 2000). Microsatellites can be used for estimating the genetic distance (Rehman and Khan, 2009), genetic diversity (Mao et al., 2008), individual profiles and paternity test (Zhang et al., 2010; Radko et al., 2010), relationship among livestock breeds (Maretto et al., 2012), and evaluating mutation drift equilibrium of animals (Kathiravan et al., 2009).

Moreover, information about potency of carcass production in the SO cattle still limited. Lack of information about carcass production is one of the causes of the lack of interest of Indonesian beef industry to develop the SO cattle fattening and breeding bussiness. Therefore, continuous studies are needed to explore information about genetic diversity and potency of carcass production in the SO cattle. The objectives of this study was to evaluate genetic diversity of the SO cattle based on DNA microsatellites and also to study the potency of the SO cattle based on carcass productivity.

\section{MATERIALS AND METHODS}

\section{Animal and Blood Samples}

Blood samples were collected from 28 individual cattle belonging to PT. KAR Farm, West Java. Blood samples (3-5 ml) were taken from cattle coccigea vein using Venoject and collected in Vaccutainer tubes contained anticoagulant. The blood samples were used for obtaining DNA samples through the DNA extraction process using DNeasy ${ }^{\circledR}$ Blood \& Tissue Kit (Qiagen, Germany) following the producer's method.

Productivity of the SO cattle were analysed from data of carcass and skin weight. Data of carcass and skin weight were obtained from 506 individual cattle that slaughtered in Karawaci abattoir, Banten, Indonesia from November 2013 to September 2014. Animals was slaughtered with consideration of animal welfare and "halal" way.

\section{Primers and DNA Amplification}

Twelve microsatellite labelled primers that recommended by FAO (2011) were used in Polymerase Chain Reaction (PCR) process. Primers sequen, annealing temperature, range of PCR product size, and label that used are shown in Table 1. The PCR reagent composition is as follows: KAPA2G Robust HotStart ReadyMix PCR Kit ( $1^{\text {st }}$ BASE, Malaysia) $(18 \mu \mathrm{l})$, forward and reverse labelled primers $(2.8 \mu \mathrm{l})$, DW $(10 \mu \mathrm{l})$, and DNA sample $(1.4 \mu 1)$. Program in the PCR machine (Eppendorf, Germany) is set as follows: $94^{\circ} \mathrm{C} ; 5$ min (1 cycle), 35 cycles consisting of three stages: (1) $94^{\circ} \mathrm{C} ; 30$ seconds, (2) $51-59^{\circ} \mathrm{C}$; 30 seconds (depends on primers), and $(3) 72^{\circ} \mathrm{C}$; 30 seconds, followed by 1 cycle at $72^{\circ} \mathrm{C}$; 5 minutes. The PCR products then visualized by electrophoresis using 2\% agarose gel and followed by ethidium bromide staining. The multiplex DNA fragment analysis was used for allele identification. The multiplex DNA fragment analysis was conducted in $1^{\text {st }}$ BASE Laboratorium, Malaysia.

\section{Data Analysis}

Result of the multiplex DNA fragment analysis was processed using CONVERT ver. 1.3.1 (Glaubitz, 2004), CERVUS ver. 3.0.7 (Kalinowski et al., 2007), and POPGENE ver. 1:32 (Yeh and Boyle, 1997) programs. The CONVERT program was used for conversion the length of alleles which were observed for each individual sample to assure suitability for further 
Table1. Information of 12 Microsatellite Primer Used in the Study Based on FAO (2011)

\begin{tabular}{|c|c|c|c|c|}
\hline Locus & Sequen $\left(5^{\prime}-3^{\prime}\right)$ & Label & $\begin{array}{l}\text { Annealing } \\
\text { Temp. }\left({ }^{\circ} \mathrm{C}\right)\end{array}$ & $\begin{array}{l}\text { Size of PCR } \\
\text { Product (bp) }\end{array}$ \\
\hline \multirow[t]{2}{*}{ TGLA227 } & F: CGAATTCCAAATCTGTTAATTTGCT & Fam & 55 & $75-105$ \\
\hline & R: ACAGACAGAAACTCAATGAAAAGCA & & & \\
\hline \multirow[t]{2}{*}{ SPS113 } & F: CCTCCACACAGGCTTCTCTGACTT & Hex & 55 & $132-170 *$ \\
\hline & R: CCTAACTTGCTTGAGTTATTGCCC & & & \\
\hline \multirow[t]{2}{*}{ BM1824 } & F: GAGCAAGGTGTTTTTCCAATC & Tamra & 57 & $176-197$ \\
\hline & R: CATTCTCCAACTGCTTCCTTG & & & \\
\hline \multirow[t]{2}{*}{ ЕTH225 } & F: ATCACCTTGCCAATATTTCC & Hex & 55 & $131-159$ \\
\hline & R: ACATGACAGCCAGCTGCTACT & & & \\
\hline \multirow[t]{2}{*}{ INRA023 } & F: GAGTAGAGCTACAAGATAAACTTC & Tamra & 55 & $195-225$ \\
\hline & R: TAACTACAGGGTGTTAGATGAACTCA & & & \\
\hline \multirow[t]{2}{*}{ TGLA122 } & F: CCCTCCTCCAGGTAAATCAGC & Fam & 57 & $136-184$ \\
\hline & R: AATCACATGGCAAATAAGTACATAC & & & \\
\hline \multirow[t]{2}{*}{ CSSM66 } & F: ACACAAATCCTTTCTGCCAGCTGA & Hex & 59 & 171-209 \\
\hline & R: AATTTAATGCACTGAGGAGCTTGG & & & \\
\hline \multirow[t]{2}{*}{ ILSTS006 } & F: TGTCTGTATTTCTGCTGTGG & Tamra & 59 & 277-309 \\
\hline & R: ACACGGAAGCGATCTAAACG & & & \\
\hline \multirow[t]{2}{*}{ BM1818 } & F: AGCTGGGAATATAACCAAAGG & Tamra & 59 & $48-278$ \\
\hline & R: AGTGCTTTCAAGGTCCATGC & & & \\
\hline \multirow[t]{2}{*}{ SPS115 } & F: AAAGTGACACAACAGCTTCTCCAG & Fam & 57 & $234-258$ \\
\hline & R: AACGAGTGTCCTAGTTTGGCTGTG & & & \\
\hline \multirow[t]{2}{*}{ TGLA126 } & F: CTAATTTAGAATGAGAGAGGCTTCT & Fam & 58 & $115-131$ \\
\hline & R:TTGGTCTCTATTCTCTGAATATTCC & & & \\
\hline \multirow[t]{2}{*}{ TGLA53 } & F: CAGCAGACAGCTGCAAGAGTTAGC & Hex & 51 & $143-191$ \\
\hline & R: CTTTCAGAAATAGTTTGCATTCATGCAG & & & \\
\hline
\end{tabular}

*Based on on Movahedin et al. (2010); bp = base pair

analysis by POPGENE and CERVUS program. Data of the allele frequencies, the heterozygosity, the genetic distance, and the PIC (Polymorphism Information Content) value were obtained from POPGENE ver. 1:32 and CERVUS ver. 3.0.7 analysis result.

Data of cattle productivity was calculated using MINITAB ver. 14 and analysed with descriptive analysis including mean of live weight, carcass weight, carcass percentage, skin weight, and skin percentage. Data of carcass and skin percentage was divided into sixteen category based on live weight before slaughter. Standard normality test for the data of live weight, carcass weight, and skin weight was conducted to ensure the data were normally distributed.

\section{RESULTS AND DISCUSSION}

PCR products for 12 microsatellite loci in this study were in good quality and can be used for allele identification using multiplex DNA fragment analysis. Variation of alleles was detected and followed by analysis of the allele frequency, the heterozygosity, and the PIC value. Allele frequency distribution of each primer pair 
Table 2. Distribution of the Allele Frequency for 12 Microsatellite Loci in the SO Cattle Population

\begin{tabular}{|c|c|c|c|c|c|}
\hline Locus & Allele & Allele Frequency & Locus & Allele & Allele Frequency \\
\hline \multirow[t]{7}{*}{ BM1824 } & 181 & 0.214 & ETH225 & 135 & 0.229 \\
\hline & 183 & 0.571 & & 139 & 0.042 \\
\hline & 185 & 0.143 & & 143 & 0.146 \\
\hline & 189 & 0.018 & & 145 & 0.021 \\
\hline & 195 & 0.018 & & 149 & 0.021 \\
\hline & 197 & 0.018 & & 151 & 0.042 \\
\hline & 199 & 0.018 & & 155 & 0.500 \\
\hline \multirow[t]{8}{*}{ SPS113 } & 131 & 0.161 & TGLA53 & 135 & 0.816 \\
\hline & 133 & 0.232 & & 137 & 0.079 \\
\hline & 135 & 0.036 & & 139 & 0.026 \\
\hline & 137 & 0.321 & & 141 & 0.026 \\
\hline & 139 & 0.179 & & 161 & 0.053 \\
\hline & 141 & 0.036 & CSSM66 & 178 & 0.161 \\
\hline & 147 & 0.018 & & 180 & 0.054 \\
\hline & 157 & 0.018 & & 182 & 0.036 \\
\hline \multirow[t]{9}{*}{ SPS115 } & 242 & 0.161 & & 196 & 0.018 \\
\hline & 244 & 0.446 & & 198 & 0.018 \\
\hline & 246 & 0.054 & & 220 & 0.714 \\
\hline & 250 & 0.054 & TGLA126 & 111 & 0.018 \\
\hline & 252 & 0.125 & & 117 & 0.143 \\
\hline & 254 & 0.054 & & 119 & 0.054 \\
\hline & 258 & 0.018 & & 121 & 0.018 \\
\hline & 262 & 0.018 & & 123 & 0.286 \\
\hline & 264 & 0.071 & & 125 & 0.304 \\
\hline \multirow[t]{10}{*}{ TGLA122 } & 136 & 0.192 & & 127 & 0.179 \\
\hline & 140 & 0.039 & ILSTS006 & 290 & 0.018 \\
\hline & 142 & 0.058 & & 292 & 0.054 \\
\hline & 144 & 0.115 & & 294 & 0.482 \\
\hline & 152 & 0.269 & & 296 & 0.250 \\
\hline & 154 & 0.115 & & 298 & 0.161 \\
\hline & 158 & 0.019 & & 300 & 0.018 \\
\hline & 160 & 0.019 & & 302 & 0.018 \\
\hline & 162 & 0.154 & INRA023 & 197 & 0.074 \\
\hline & 164 & 0.019 & & 199 & 0.056 \\
\hline \multirow[t]{9}{*}{ TGLA227 } & 78 & 0.786 & & 201 & 0.093 \\
\hline & 80 & 0.036 & & 203 & 0.111 \\
\hline & 84 & 0.036 & & 205 & 0.019 \\
\hline & 86 & 0.018 & & 209 & 0.056 \\
\hline & 88 & 0.018 & & 211 & 0.037 \\
\hline & 92 & 0.036 & & 215 & 0.556 \\
\hline & 94 & 0.018 & BM1818 & 262 & 0.214 \\
\hline & 96 & 0.018 & & 264 & 0.786 \\
\hline & 100 & 0.036 & & & \\
\hline
\end{tabular}


is presented in Table 2.

The calculation of the heterozygosity and the PIC values for all locus has been conducted (data are shown in Table 3.). The heterozygosity value ranged from 0.143 to 1.000 (mean 0.536). This value was very high $(\mathrm{P}>0.5)$ and indicates the number of heterozygous samples. Therefore, all the microsatellite locus in this study were highly polymorphic. The lowest heterozygosity value was 0.143 (BM1818) and the highest value was 1.000 (SPS113). The PIC value for each locus was estimated according to Botstein et al. (1980). The PIC value at 12 microsatellite loci that used in this study was more than 0.5 (PIC $>0.5$ ). Hence, every locus in this study was highly informative for detecting the level of genetic diversity in population.

The highest PIC value in this study was 0.814 (locus TGLA122), while the lowest value was 0.280 (locus BM1818). The low PIC and Ho values for locus BM1818 in the SO cattle in this study can be explained by several factors including null alleles, assortative mating, the Wahlund effect, selection against heterozygotes, inbreeding, or a combination of all these factors (Cervini et al., 2006). Moreover, the low value of heterozygosity may indicate that a certain breeds are relatively well-conserved (Czernekova et al., 2006).

Compared to the results from other studies that also used microsatellite which were mostly identical with our study, some differences can be observed. The differences may be on the minimum and maximum allele size, the number of observed alleles and also the PIC value. The comparison is presented in Table 4. Characteristics of microsatellite that naturally was highly polymorphic was the influential factor that caused the differences in size range of allele and the number of observed alleles. The PIC value and observed heterozygosity (Ho) value in this study for locus TGLA227 was low. This condition was same with Cervini et al. (2006) but contrast with Kesvulu et al. (2009) and Riojas-Valdes et al. (2009) reports that found locus TGLA227 with higher PIC and Ho values. In other hand, PIC and Ho values in locus TGLA53 in this study was low as well as other reports (Kesvulu et al., 2009; Cervini et al., 2006).

Data of carcass productivity was classified into sixteen groups based on the slaughter weight (Table 5). Data of the slaughter weight was ranged from $250 \mathrm{~kg}$ to $650 \mathrm{~kg}$. Most of the $\mathrm{SO}$ cattle slaughtered in year 2013 and 2014 was in

Table 3. Genetic Diversity in the SO Cattle

\begin{tabular}{lllcccc}
\hline \multicolumn{1}{c}{ Locus } & $\mathrm{N}$ & $\mathrm{na}$ & $\mathrm{ne}$ & $\mathrm{Ho}$ & $\mathrm{He}$ & $\mathrm{PIC}$ \\
\hline TGLA227 & 56 & 9 & 1.6033 & 0.357 & 0.383 & 0.368 \\
SPS113 & 56 & 8 & 4.5848 & 1.000 & 0.796 & 0.750 \\
BM1824 & 56 & 7 & 2.5372 & 0.286 & 0.617 & 0.560 \\
TGLA122 & 52 & 10 & 6.0357 & 0.808 & 0.851 & 0.814 \\
CSSM66 & 56 & 6 & 1.8491 & 0.571 & 0.468 & 0.428 \\
BM1818 & 56 & 2 & 1.5077 & 0.143 & 0.343 & 0.280 \\
ETH225 & 48 & 7 & 3.0476 & 0.875 & 0.686 & 0.630 \\
INRA023 & 54 & 8 & 2.9160 & 0.593 & 0.670 & 0.635 \\
ILSTS006 & 56 & 7 & 3.0806 & 0.321 & 0.688 & 0.629 \\
SPS115 & 56 & 9 & 3.9200 & 0.643 & 0.759 & 0.721 \\
TGLA126 & 56 & 7 & 4.3556 & 0.571 & 0.784 & 0.734 \\
TGLA53 & 38 & 5 & 1.4795 & 0.263 & 0.333 & 0.310 \\
\multicolumn{1}{c}{ Mean } & 53 & 7.08 & 3.0764 & 0.536 & 0.615 & 0.572 \\
\multicolumn{1}{c}{ Std. Dev. } & & 2.11 & 1.4265 & 0.268 & 0.186 & \\
\hline
\end{tabular}

$\mathrm{n}_{\mathrm{A}}=$ observed number of allele; ne = effective number of allele; Ho = observed heterozygosities; $\mathrm{He}=$ expected heterozygosities; $\mathrm{PIC}=$ polymorphism information content; s.d. $=$ standard deviation 
Table 4. Comparison of the Size Range, the Heterozygosity, and the PIC of Microsatellite Loci in the Bos indicus Cattle Study

\begin{tabular}{|c|c|c|c|c|c|}
\hline Locus & Parameter & A & B & $\mathrm{C}$ & $\mathrm{D}$ \\
\hline \multirow[t]{3}{*}{ TGLA227 } & Range (bp) $\left[\mathrm{n}_{\mathrm{A}}\right]$ & $77-89[5]$ & $75-97[6]$ & $76-83[6]$ & $78-100[9]$ \\
\hline & Ho & 0.739 & 0.368 & 0.7414 & 0.357 \\
\hline & PIC & 0.565 & 0.39 & 0.9926 & 0.368 \\
\hline \multirow[t]{3}{*}{ BM1824 } & Range (bp) $\left[\mathrm{n}_{\mathrm{A}}\right]$ & 179-197 [6] & $176-196[10]$ & $177-192$ [9] & $181-199$ [7] \\
\hline & Ho & 0.522 & 0.677 & 0.6294 & 0.286 \\
\hline & PIC & 0.619 & 0.612 & 0.9998 & 0.56 \\
\hline \multirow[t]{3}{*}{ ETH225 } & Range (bp) $\left[\mathrm{n}_{\mathrm{A}}\right]$ & $146-158[4]$ & $138-162[10]$ & $142-161[8]$ & $135-155$ [7] \\
\hline & Ho & 0.304 & 0.323 & 0.7328 & 0.875 \\
\hline & PIC & 0.308 & 0.6683 & 0.9996 & 0.63 \\
\hline \multirow[t]{3}{*}{ INRA023 } & Range (bp) $\left[\mathrm{n}_{\mathrm{A}}\right]$ & $197-215[6]$ & 194-216 [9] & & 197-215 [8] \\
\hline & Ho & 0.609 & 0.541 & & 0.593 \\
\hline & PIC & 0.536 & 0.835 & & 0.635 \\
\hline \multirow[t]{3}{*}{ TGLA122 } & Range (bp) $\left[\mathrm{n}_{\mathrm{A}}\right]$ & $137-197$ [9] & $133-165[16]$ & $136-167[10]$ & 136-164 [10] \\
\hline & Ho & 0.826 & 0.661 & 0.790 & 0.808 \\
\hline & PIC & 0.809 & 0.805 & 0.999 & 0.814 \\
\hline \multirow[t]{3}{*}{ SPS115 } & Range (bp) $\left[\mathrm{n}_{\mathrm{A}}\right]$ & $245-255$ [5] & & $140-156$ [11] & 242-264 [7] \\
\hline & Ho & 0.783 & & 0.7155 & 0.643 \\
\hline & PIC & 0.726 & & 0.9996 & 0.721 \\
\hline \multirow[t]{3}{*}{ TGLA126 } & Range (bp) $\left[\mathrm{n}_{\mathrm{A}}\right]$ & $118-130$ [7] & $109-127[8]$ & & $111-127$ [7] \\
\hline & Ho & 1.000 & 0.847 & & 0.571 \\
\hline & PIC & 0.776 & 0.773 & & 0.734 \\
\hline \multirow[t]{3}{*}{ TGLA53 } & Range (bp) $\left[\mathrm{n}_{\mathrm{A}}\right]$ & $159-179$ [7] & $160-190$ [13] & & $135-161[5]$ \\
\hline & Ho & 0.304 & 0.352 & & 0.263 \\
\hline & PIC & 0.586 & 0.405 & & 0.31 \\
\hline
\end{tabular}

$\mathrm{n}_{\mathrm{A}}=$ observed number of alleles; $\mathrm{bp}=$ base pair; $\mathrm{A}=$ Kesvulu et al. (2009); $\mathrm{B}=$ Cervini et al. (2006); $\mathrm{C}=$ Riojas-Valdes et al. (2009); D = this study

range of 351-475 kg slaughter weight with carcass percentage ranging from $52.89 \%$ to $53.43 \%$. The highest carcass weight $(358.06 \mathrm{~kg})$ and also highest carcass percentage $(56.34 \%)$ was obtained from cattle in range of $626-650 \mathrm{~kg}$ slaughter weight. In other hand, the lowest carcass weight $(137.4 \mathrm{~kg})$ and lowest carcass percentage $(51.42 \%)$ was obtained from cattle in range of 250-275 kg slaughter weight.

The results of this study showed that the SO cattle has excellent potential as beef cattle according to the ability of the SO cattle to gain a fairly higher carcass percentage $(51.42 \%$ $56.34 \%$ ) compare with other local breed cattle in Indonesia. Several studies of the SO cattle in Indonesia was reported and it can be summarized that the lowest carcass percentage of the SO cattle ever reported was $46.8 \%$ (Sumadi and Siliwolu, 2004) while the highest carcass percentage ever reported was $53.89 \%$ (Ngadiyono, 1995). Data of 
Table 5. Distribution of the Carcass Weight and the Skin Weight of the SO Cattle

\begin{tabular}{|c|c|c|c|c|c|c|}
\hline $\begin{array}{c}\text { Weight } \\
\text { Range (kg) }\end{array}$ & $\begin{array}{l}\text { Slaughter } \\
\text { Weight (kg) }\end{array}$ & $\begin{array}{c}\text { Carcass Weight } \\
(\mathrm{kg})\end{array}$ & $\begin{array}{c}\text { Carcass } \\
\text { Percentage }\end{array}$ & $\begin{array}{l}\text { Skin Weight } \\
(\mathrm{kg})\end{array}$ & $\begin{array}{c}\text { Skin } \\
\text { Percentage }\end{array}$ & $\mathrm{n}$ \\
\hline & & ( & s.d.).. & & & \\
\hline $250-275$ & $267.80 \pm 8.00$ & $137.40 \pm 9.85$ & $51.42 \pm 2.27$ & $18.33 \pm 0.58$ & $6.87 \pm 0.29$ & 3 \\
\hline $276-300$ & $284.18 \pm 7.35$ & $148.81 \pm 8.46$ & $52.37 \pm 2.81$ & $20.36 \pm 2.58$ & $7.16 \pm 0.78$ & 11 \\
\hline $301-325$ & $313.80 \pm 6.33$ & $167.13 \pm 6.35$ & $53.27 \pm 2.10$ & $23.87 \pm 5.42$ & $7.60 \pm 1.68$ & 15 \\
\hline $326-350$ & $339.19 \pm 8.21$ & $179.34 \pm 7.15$ & $52.88 \pm 1.94$ & $26.00 \pm 3.72$ & $7.67 \pm 1.11$ & 21 \\
\hline $351-375$ & $366.53 \pm 6.63$ & $194.56 \pm 7.22$ & $53.09 \pm 1.81$ & $27.47 \pm 3.15$ & $7.50 \pm 0.87$ & 57 \\
\hline $376-400$ & $386.38 \pm 6.99$ & $204.57 \pm 7.99$ & $52.95 \pm 1.87$ & $28.63 \pm 3.55$ & $7.41 \pm 0.91$ & 64 \\
\hline $401-425$ & $413.49 \pm 6.95$ & $218.73 \pm 9.15$ & $52.89 \pm 1.89$ & $30.70 \pm 3.43$ & $7.42 \pm 0.81$ & 77 \\
\hline $426-450$ & $436.27 \pm 7.13$ & $230.98 \pm 9.12$ & $52.94 \pm 1.75$ & $32.20 \pm 2.57$ & $7.38 \pm 0.59$ & 70 \\
\hline $451-475$ & $463.08 \pm 7.59$ & $247.45 \pm 10.74$ & $53.43 \pm 2.08$ & $33.59 \pm 4.02$ & $7.26 \pm 0.88$ & 64 \\
\hline $476-500$ & $486.92 \pm 7.83$ & $264.06 \pm 14.72$ & $54.23 \pm 2.85$ & $35.61 \pm 4.80$ & $7.32 \pm 1.00$ & 36 \\
\hline $501-525$ & $511.26 \pm 6.45$ & $279.43 \pm 13.28$ & $54.65 \pm 2.36$ & $36.56 \pm 4.58$ & $7.15 \pm 0.90$ & 27 \\
\hline $526-550$ & $539.24 \pm 6.86$ & $289.90 \pm 12.67$ & $53.76 \pm 2.11$ & $37.00 \pm 3.21$ & $6.86 \pm 0.60$ & 21 \\
\hline $551-575$ & $561.90 \pm 7.29$ & $306.20 \pm 17.82$ & $54.48 \pm 2.83$ & $37.60 \pm 4.43$ & $6.69 \pm 0.77$ & 20 \\
\hline $576-600$ & $582.75 \pm 8.21$ & $317.25 \pm 5.44$ & $54.45 \pm 1.43$ & $39.13 \pm 3.83$ & $6.71 \pm 0.66$ & 8 \\
\hline $601-625$ & $610.25 \pm 8.22$ & $333.50 \pm 5.80$ & $54.66 \pm 1.06$ & $40.50 \pm 2.38$ & $6.64 \pm 0.41$ & 4 \\
\hline $626-650$ & $635.50 \pm 6.91$ & $358.06 \pm 15.35$ & $56.34 \pm 2.24$ & $44.38 \pm 4.98$ & $6.98 \pm 0.75$ & 8 \\
\hline
\end{tabular}

Total number of animal; 506; s.d.= standard deviation; $\mathrm{n}=$ number of animal

carcass percentage for another local breed cattle in Indonesia was also reported. Carvalho et al. (2010) have reported that the carcass percentage of the Ongole Grade (PO) cattle was $49.4 \%$ while the SimPO (crossing result from the Simmental and the PO cattle) was 51.18\%. Ngadiyono (1995) reported that the carcass percentage of the Brahman cross cattle was $54.18 \%$. In addition, Muthalib (2003) reported that the carcass percentage of the Bali cattle was $50.19 \%$. According to average daily gain values, Ngadiyono (1995) reported that the SO cattle can gain $0.85 \mathrm{~kg} /$ day in feedlots condition while the PO cattle can gain $0.86 \mathrm{~kg}$ /day (Carvalho et al., 2010).

\section{CONCLUSION}

The results of genetic characterization showed that all the microsatellite locus in this study were highly polymorphic and highly informative for detecting the level of genetic diversity in the SO cattle population. The results of carcass productivity study showed that the SO cattle has excellent potential as beef cattle according to the ability to gain higher carcass percentage $(51.42 \%$ - 56.34\%) compare with other local breeds cattle in Indonesia.

\section{REFERENCES}

Bennet, P. 2000. Microsatellites. J. Clin. Pathol. Mol. Pathol. 53:177-183

Botstein, D., R.L. White, M. Skolnick, and R.W. Davis. 1980. Construction of a genetic linkage map in man using restriction fragment length polymorphisms. Am. J. Hum. Genet. 32(3):314-331

Carvalho, M.C, Suparno and N. Ngadiyono. 2010. Pertumbuhan dan produksi karkas sapi Peranakan Ongole dan Simental-Peranakan Ongol jantan yang dipelihara secara feedlot. 
Buletin Peternakan. 34(1):38-46

Cervini, M., F. Henrique-Silva, N. Mortari, and E. Matheucci Jr. 2006. Genetic variability of 10 microsatellite markers in the characterization of Brazilian Nellore cattle (Bos indicus). Genet. Mol. Biol. 29(3):486490

Czerneková, V., T. Kott, G. Dudková, Z. Sztankóová, and J. Soldát. 2006. Genetic diversity between seven Central European cattle breeds as revealed by microsatellite analysis. Czech J. Anim. Sci. 51(1):1-7

FAO. 2011. Molecular genetic characterization of animal genetic resources. FAO Animal Production and Health Guidelines. Available at http://www.fao.org/docrep/ 014/i2413e/i2413e00.htm.

Glaubitz, J.C. 2004. Convert: a user friendly program to reformat diploid genotypic data for commonly used population genetic software packages. Mol. Ecol. Notes. 4:309310

Hardjosubroto, W. 2004. Alternatif kebijakan pengelolaan berkelanjutan sumberdaya genetik sapi potong lokal dalam sistem perbibitan ternak nasional. Proceedings, Lokakarya Nasional Sapi Potong, Yogyakarta, 8-9 October 2004. P. 29-34.

Kalinowski S.T., M.L. Taper and T.C. Marshall. 2007. Revising how the computer program CERVUS accommodates genotyping error increases success in paternity assignment. Mol. Ecol. 16:1099-1106

Kathiravan, P., B.P. Mishra, R.S. Kataria and D.K. Sadana. 2009. Evaluation of genetic architecture and mutation drift equilibrium of Marathwada buffalo population in Central India. Livest. Sci. 121:288-293

Kesvulu, P.C., G.N. Rao, A.S.N. Ahmed and B.R. Gupta. 2009. Molecular genetic characterization of Pungular cattle. Tamilnadu J. Vet. Anim.Sci.5(5):179-185

Mao, Y., H. Chang, Z. Yang, L. Zhang, M. Xu, G. Chang, W. Sun, G. Song and D. Ji. 2008. The analysis of genetic diversity and differentiation of six Chinese cattle populations using microsatellite markers. J. Genet. Genomics 35:25-32

Maretto, F., J. Ramljak, F. Sbarra, M. Penasa, R.Mantovani, A. Ivankovic and G. Bittante. 2012. Genetic relationshipships among Italian and Croatian Podolian cattle breeds assessed by microsatellite markers. Livest.
Sci. 150: 256-264

Ministry of Agriculture of the Republic of Indonesia. 2014. Ministerial Decree No. 427/Kpts/SR.120/3/2014 tentang penetapan rumpun sapi Sumba Ongole. Available at http://bibit.ditjennak.pertanian.go.id/content/ sapi-sumba-ongole.

Movahedin, M.R., C. Amirinia, A. Noshary and A.A. Mirhadi. 2010. Detection of genetic variation in sample of Iranian proofed Holstein cattle by using microsatellite marker. Afr. J. Biotechnol. 9(53):9042-9045

Muthalib, R.A. 2003. Carcass and meat characteristics of F1 crossbred among Bali female cattle and four sire breeds. J. Indonesian Trop. Anim. Agric. 28(1):7-10.

Ngadiyono, N. 1995. Pertumbuhan serta sifat-sifat karkas dan daging sapi Sumba Ongole, Brahman Cross dan Australian Commercial Cross yang dipelihara secara intensif pada berbagai bobot potong. Dissertation. Bogor Agricultural University, Bogor.

Radko, A. 2010. Application of a complementary set of 10 microsatellite DNA markers for parentage verification in Polish Red cattle. Ann. Anim. Sci. 10(1):9-15

Rehman, M.S. and M.S. Khan. 2009. Genetic Diversity of Hariana and Hissar cattle from Pakistan using microsatellite analysis. Pakistan Vet. J. 29(2):67-71

Riojas-Valdes, V.M., J.C. Gomes-de-la-Fuente, J.M. Garza-Lozano, D.C. Gallardo-Blanco, J.N. De Tellitu-Schutz, A. Wong-Gonzales, G. Davalos-Aranda and J.A. SalinasMelendez. 2009. Exclusion probabilities of 8 DNA microsatellites in 6 cattle breeds from Northeast Mexico. J. Anim. Vet. Adv. $8(1): 62-66$

Sumadi and Siliwolu. 2004. Penelitian mutu genetik sapi Ongole dan Brahman di kabupaten Sumba Timur, Nusa Tenggara Timur. Proceedings, Lokakarya Nasional Sapi Potong, Yogyakarta, 8-9 October 2004. P. 31-41.

Yeh, F.C. and T.J.B. Boyle. 1997. Population genetic analysis of co-dominant and dominant markers and quantitative traits. Belg. J. Bot. 129:157

Zhang, Y., Y. Wang, D. Sun, Y. Yu and Y. Zhang. 2010. Validation of 17 microsatellite markers for parentage verification and identity test in Chinese Holstein cattle. Asian-Aust. J. Anim. Sci. 23(4): 425-429 